\title{
Anatomic Variations in Relation to the Origin of the Musculocutaneous Nerve: Absence and Non-Perforation of the Coracobrachialis Muscle. Anatomical Study and Clinical Significance
}

\author{
Variaciones Anatómicas en Relación al Origen del Nervio Musculocutáneo: \\ Ausencia y no Perforación del Músculo Coracobraquial: Estudio Anatómico y Significado Clínico
}

Daniel Raúl Ballesteros Larrotta ${ }^{1}$; Pedro Luis Forero Porras $^{2}$ \& Luis Ernesto Ballesteros Acuña ${ }^{1}$

BALLESTEROS, D. R.; FORERO, P. L. \& BALLESTEROS, L. E. Anatomic variations in relation to the origin of the musculocutaneous nerve: Absence and non-perforation of the coracobrachialis muscle. Anatomical study and clinical significance. Int. J. Morphol., 36(2):425$429,2018$.

SUMMARY: The most frequent anatomic variations of the musculocutaneous nerve could be divided in two main groups: communicating branches with the median nerve and variations in relation to the origin, which in turn can be subdivided into absence of the nerve and non-perforation of the coracobrachialis muscle. Unusual clinical symptoms and/or unusual physical examination in patients with motor disorders, could be explained by anatomic variations of the musculocutaneous nerve. A total of 106 arms were evaluated, corresponding to 53 fresh male cadavers who were undergoing necropsy. The presence or absence of the musculocutaneous nerve was evaluated and whether it pierced the coracobrachialis muscle or not. The lengths of the motor branches and the distances from its origins to the coracoid process were measured. In 10 cases $(9.5 \%)$ an unusual origin pattern was observed, of which six (5.7\%) correspond to non-perforation of the coracobrachialis muscle and four $(3.8 \%)$ correspond to absence of the nerve. The length of the branch for the brachialis muscle was $37.7 \pm 15.4 \mathrm{~mm}$ and for the short and long heads of the biceps $27.6 \pm 11.7 \mathrm{~mm}$ and $33.2 \pm 10.1 \mathrm{~mm}$ respectively. The study showed that our population has similar prevalence of absence of the musculocutaneous nerve and non-perforation of the coracobrachialis muscle compared to previous reports in different populations. Moreover, there was no statistical correlation between the sides and the evaluated variables.

KEY WORDS: Anatomic variation; Musculocutaneous nerve; Median nerve; Brachial plexus; Arm injuries.

\section{INTRODUCTION}

The lateral cord of the brachial plexus usually bifurcates at the infraclavicular level, giving origin to the musculocutaneous nerve $(\mathrm{MCN})$ and the lateral root of the median nerve (MN) (Ballesteros et al., 2015). The fibers for the MCN originates from C5, C6 and C7 nerve roots. The MCN gives off a branch for the coracobrachialis muscle $(\mathrm{CbM})$ before piercing it, and then innervates the biceps brachii muscle and brachialis muscle (Standring, 2016). In its trajectory, the MCN goes through the deep fascia, lateral to the biceps tendon and then continues as a sensitive nerve, the lateral antebrachial cutaneous nerve (Osborne et al., 2000; Standring).

The anatomic variations of the $\mathrm{MCN}$ are present in one of every three arms (Choi et al., 2002). The most frequent anatomic variations of the MCN could be divided in two main groups: communicating branches with the $\mathrm{MN}$ and variations in relation to the origin, which in turn can be subdivided into absence of the MCN and non-perforation of the $\mathrm{CbM}$. These variations have been reported in ranges between $0.8-8.3 \%$ and $1.3-11.1 \%$ respectively (Venieratos \& Anagnostopoulou, 1998; Choi et al.; Loukas \& Aqueelah, 2005; Guerri-Guttenberg et al., 2009).

Injuries to the $\mathrm{MCN}$ are associated with weakness of arm flexion and sensory loss along the lateral aspect of the forearm. Unusual clinical symptoms and/or unusual physical examination in patients with motor disorders, could be explained by anatomic variations of the MCN (Beheiry, 2004). This study was therefore conducted to determine the variations of the $\mathrm{MCN}$ in relation to its origin, in a cadaveric sample of Colombian mestizo population, constituting

${ }^{1}$ Department of Basic Sciences, Medicine Faculty, Universidad Industrial de Santander. Bucaramanga, Colombia.

${ }^{2}$ Department of Pathology, Medicine Faculty, Universidad Industrial de Santander. Bucaramanga, Colombia. 
valuable information for clinical diagnosis, electromyographic procedures, nerve blocks and surgical approaches to the arm.

\section{MATERIAL AND METHOD}

This descriptive cross-sectional study was designed to determine the variations of the $\mathrm{MCN}$ in relation to its origin in 106 fresh upper extremities of 53 individuals who were undergoing necropsy at the National Institute of Forensic Medicine in Bucaramanga, Colombia. The sample met the following inclusion criteria: male individuals over 18 years of age. Furthermore, the following exclusion criteria were established: subjects with evidence of direct trauma or scars in upper extremities. A longitudinal incision along the midaxillary line was made from the coracoid process to the upper third of the forearm, which involved skin, subcutaneous tissue and brachial fascia. Subsequently, the muscular structures of the anterior compartment of the arm and the nerves derived from the lateral and medial cords of the brachial

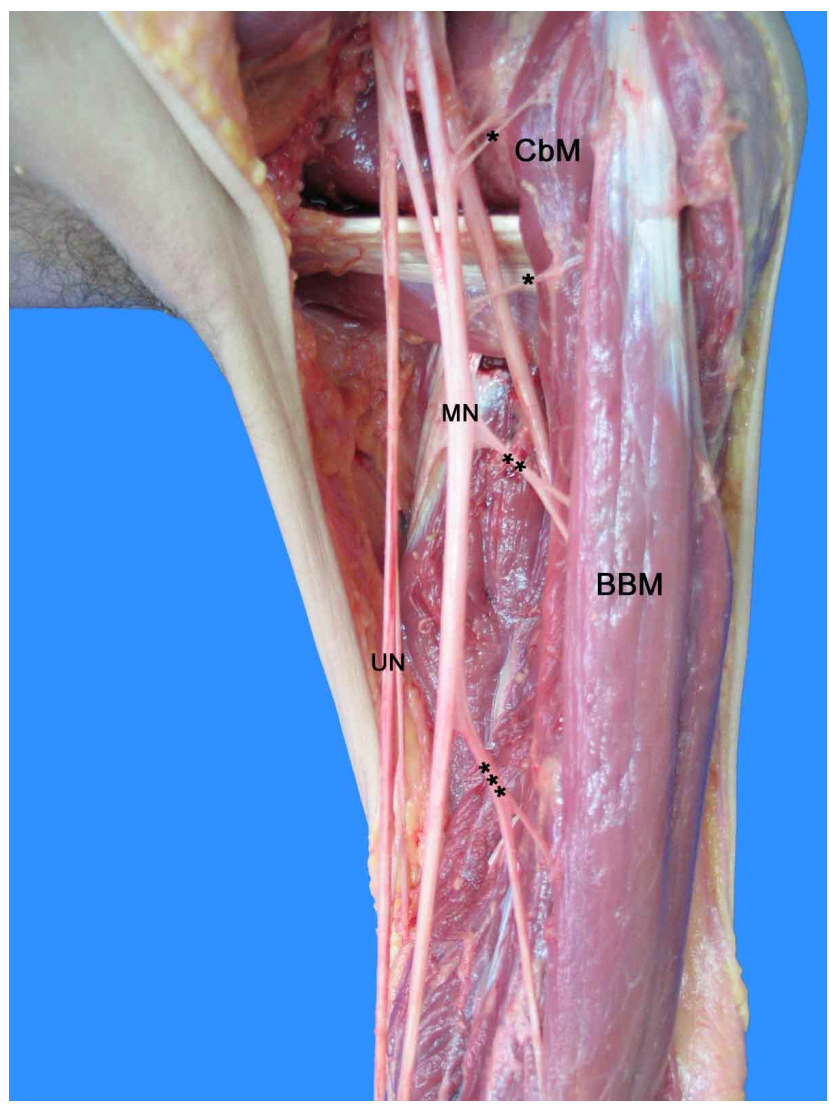

Fig. 1. Anterior compartment in a left arm. Origin of the musculocutaneous nerve from the median nerve. MCN: Musculocutaneous nerve. RN: Radial nerve. MN: Median nerve; UN: Ulnar nerve; BBM: Biceps brachii muscle. (*): Medial root of the median nerve; $(* *)$ : Lateral root of the medial nerve. plexus were dissected. The presence or absence of the MCN was evaluated and whether the MCN pierced the coracobrachialis muscle or not. Using a digital micrometer (Mitutoyo, Japan), the lengths of the motor branches and the distances from its origins to the coracoid process were measured. Continuous quantitative variables were described with their averages and standard deviations. A student's $t$ test was carried out accepting an alpha error of up to $5 \%$. The statistical analysis was performed using IBM® SPSS®.

\section{RESULTS}

In 96 arms (90.5\%) the usual origin pattern of the MCN was observed from the lateral cord of the brachial plexus. In 10 arms $(9.5 \%)$ anatomic variations in relation to the origin of the MCN were observed, corresponding to six left and four right arms. No statistically significant differences were found between the sides and the presence of a variant origin pattern $(p>0.05)$.

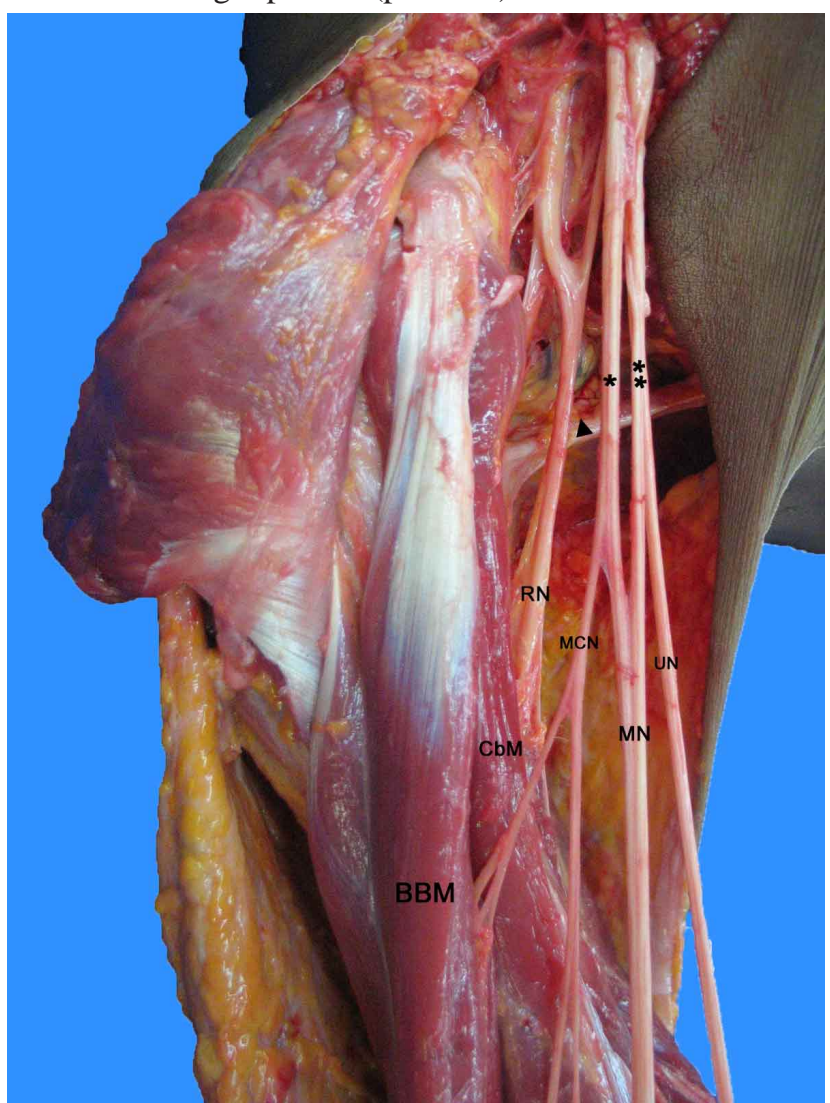

Fig. 2. Anterior compartment in a left arm. Origin of the musculocutaneous nerve at the level of the upper edge of latissimus dorsi tendon and non-perforation of the coracobrachialis muscle. MCN: Musculocutaneous nerve. RN: Radial nerve. MN: Median nerve; UN: Ulnar nerve; CbM: Coracobrachialis muscle; BBM: Biceps brachii muscle; (s): Latissimus dorsi tendon. 
In six arms $(5.7 \%)$ the MCN did not pierce the $\mathrm{CbM}$. In this group, the MCN originated directly from the lateral cord of the brachial plexus in five arms and in the remaining the $\mathrm{MCN}$ originated from the median nerve (Fig. 1). In three arms of those with an origin of the $\mathrm{MCN}$ from the lateral cord of the brachial plexus, the MCN arose at the level of the latissimus dorsi tendon, accompanied by a lateral root of the median nerve with mean length of 45.6 $\mathrm{mm}$ (Fig. 2). In the other two arms, the origin of the MCN was inferior to the latissimus dorsi tendon, accompanied by a lateral root of the median nerve with mean length of $12.0 \mathrm{~mm}$ (Fig. 3).

In four arms $(3.8 \%)$ the MCN was absent and the branches for the muscles of the anterior compartment of the arm and the lateral antebrachial cutaneous nerve originated from the MN (Fig. 4). We found bilateral case of absence of the MCN and 1 bilateral case of nonperforation of the $\mathrm{CbM}$.

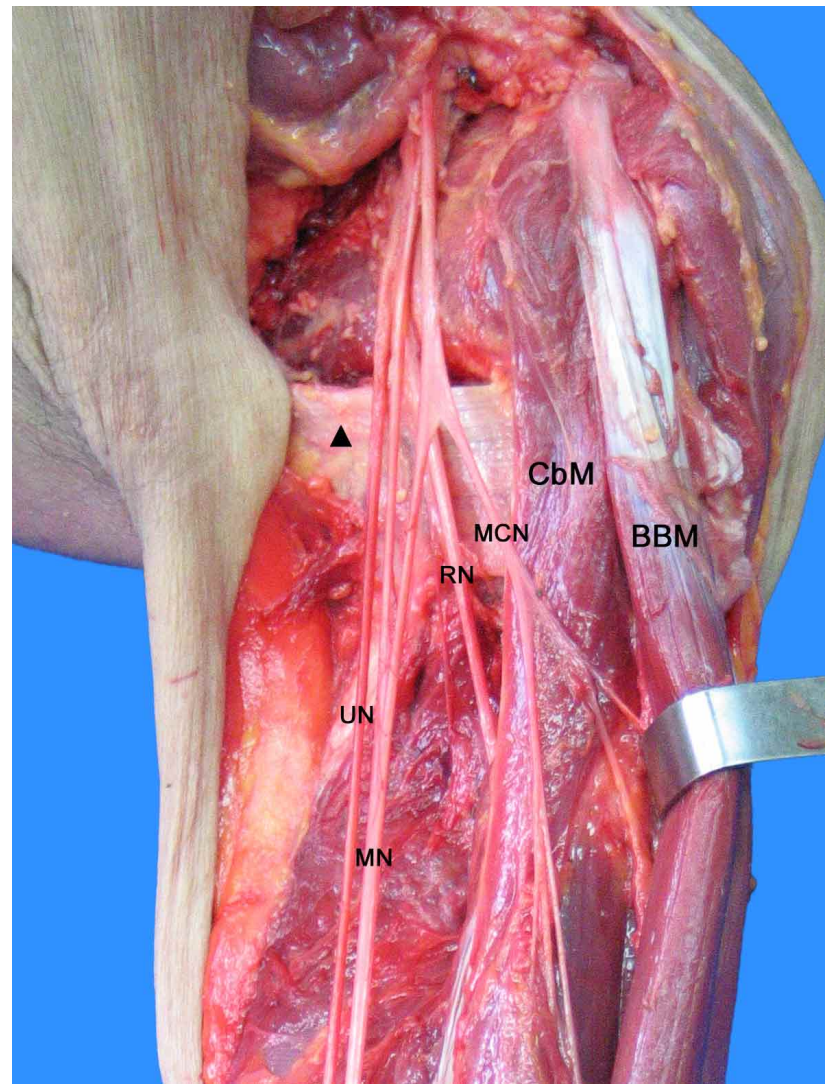

Fig. 3. Anterior compartment in a right arm. Origin of the musculocutaneous nerve inferior to the latissimus dorsi tendon and non-perforation of the coracobrachialis muscle. MCN: Musculocutaneous nerve. RN: Radial nerve. MN: Median nerve; UN: Ulnar nerve; CbM: Coracobrachialis muscle; BBM: Biceps brachii muscle; $(*)$ : Lateral cord of the brachial plexus; $(* *)$ : Medical cord of the brachial plexus; (s): Latissimus dorsi tendon.
In the variant arms, the branches for the biceps brachii muscle and brachialis muscle originated at distance from the coracoid process at a mean of $106.6 \pm 23.2 \mathrm{~mm}$ and $202.7 \pm 20.2$ $\mathrm{mm}$ respectively. The length of the branch for the brachialis muscle was at a mean of $37.7 \pm 15.4 \mathrm{~mm}$ and for the short and long heads of the biceps $27.6 \pm 11.7 \mathrm{~mm}$ and $33.2 \pm 10.1 \mathrm{~mm}$ respectively. No statistically significant differences were found between the sides and the morphometric variables $(p>0.05)$.

\section{DISCUSSION}

The MCN can travel with the lateral root of the MN and subsequently arise from the MN (Rea, 2016). In this pattern, the MCN gives off a branch to the $\mathrm{CbM}$ but without piercing it (Choi et al.). This corresponds to Le Minor (1990) classification type IV. Furthermore, the MCN originated directly from the lateral cord of the brachial plexus may have a trajectory in the arm without perforating the CbM. This pattern has been included in previous classifications of MCN and MN communications: Venieratos \& Anagnostopoulou type III and Loukas \& Aqueelah, type III. Some authors classified Le Minor types IV and V in a same group: Choi et

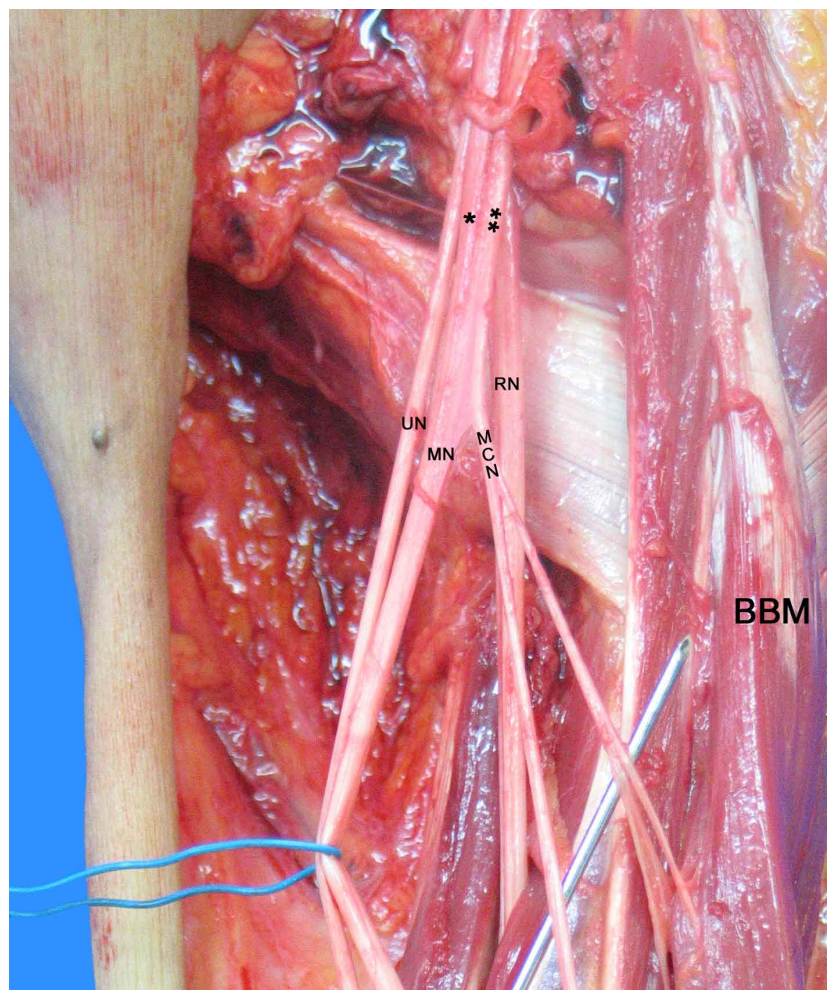

Fig. 4. Anterior compartment in a left arm. Absence of the musculocutaneous nerve. MN: Median nerve; UN: Ulnar nerve; CbM: Coracobrachialis muscle; BBM: Biceps brachii muscle; (*): Branch for the Coracobrachialis muscle; $(* *)$ : Branch for the Biceps brachii muscle; (***): Branch for the Brachialis muscle. 
al. type 1, Maeda et al. (2009) type E and Hayashi et al. (2017) type 0 . Conceptually Le Minor types IV and V correspond to a fusion between MCN and MN. In the first one the fusion dissolves and in the second it continues indefinitely.

During the embryologic development, the MCN nerve is derived relatively late. Its absence may correspond to an incomplete differentiation of the brachial plexus $(\mathrm{Bu}-$ lla et al., 2012). In the absence of the MCN, its fibers are fused with the MN forming a common trunk. In this case, the branches for the muscles of the anterior compartment of the arm and the lateral antebrachial cutaneous nerve arises from the median nerve (Maeda et al., 2009; Bulla et al.). This corresponds to Le Minor classification type V. Studies by Beheiry reported that in $\mathrm{MCN}$ absence the branch for the $\mathrm{CbM}$ may arise from the lateral cord of the brachial plexus and not from the median nerve.

The frequencies of the anatomic variations in relation to the origin of the MCN varies in different population groups (Table I). The frequency of the non-perforation of the $\mathrm{CbM}$ has been reported in a range between $1.3 \%$ and $11.1 \%$. We found a prevalence of $5.7 \%$ which is in an intermediate range with respect to previous findings. On the other side, the prevalence of the absence of the MCN has been reported in a range between $0.8 \%$ and $8.3 \%$. Our findings are consistent with the literature concerning to the frequency of this variation. Studies by Prasada Rao \& Chaudhary (2001) and Bulla et al. reported a high prevalence, however, the sample is smaller than other studies with lower frequencies. We consider that factors such as the sample size and the biological characteristics of the populations may explain the variability of the results.
Regarding to the morphometric, in our series the distances from the coracoid process to the emergence of the branches for the biceps brachii are slightly shorter compared to the findings of previous studies in non-variant arms (Yang et al., 1995; Apaydin et al., 2009). However, the distance from the coracoid process to the origin of the branch for the brachialis muscle is slightly longer compared to prior studies (Yang et al.; Apaydin et al.). Our findings are consistent with the literature concerning to the length of the branches (Yang et al.; Apaydin et al.).

The MCN has a protected location and course, deep within the arm (Tubbs, 2015). When the MCN do not pierce the $\mathrm{CbM}$, is exposed for a traumatic or iatrogenic injuries. On the other side, when the MCN is absent, an injury to the median nerve will lead to unusual clinical symptoms and/or unusual physical examination.

An adequate knowledge of anatomical variations that compromise nerve structures at the arm level is relevant for clinical practice. It allows assessment and appropriate management in those patients with motor disorders who present unusual symptomatology. In addition, this knowledge is also important during electromyography procedures, nerve blocks and surgical approaches to the arm by decreasing the risk of iatrogenia.

ACKNOWLEDGMENTS: We would like to recognize the National Institute of Forensic Medicine (Instituto Nacional de Medicina Legal y Ciencias Forenses) for supplying the anatomical specimens used in this study.

Table I. Frequencies of the anatomic variations in relation to the origin of the MCN in different population groups.

\begin{tabular}{lcccc}
\hline Author - Year & Population & S ample & Absence & Non-perforation \\
\hline Beheiry (2004) & Egyptian & 60 & $1(1.67 \%)$ & - \\
Buch-Hansen (1955) & Danish & 75 & $2(2.67 \%)$ & - \\
Bulla et al. (2012) & Italian & 25 & $2(8.00 \%)$ & - \\
Chitra (2007) & Indian & 50 & $3(6.00 \%)$ & $2(4.00 \%)$ \\
Choi et al (2002) & British & 276 & $14(5.07 \%)$ & $22(7.97 \%)$ \\
Gegenbaur (1867) & German & 41 & $3(7.32 \%)$ & - \\
Guerri-Guttenberg et al. (2009) & Argentinian & 56 & $2(3.57 \%)$ & $6(10.71 \%)$ \\
Hayashi etal. (2017) & Japanese & 130 & $2(1.54 \%)$ & - \\
Kerr (1918) & American & 175 & $3(1.71 \%)$ & - \\
Loukas \& Aqueelah (2005) & American & 119 & $1(0.84 \%)$ & $11(9.24 \%)$ \\
Maeda et al. (2009) & Japanese & 453 & $8(1.77 \%)$ & $7(1.55 \%)$ \\
Patel et al. (2013) & Indian & 80 & $2(2.50 \%)$ & $1(1.25 \%)$ \\
Prasada Rao \& Chaudhary (2001) & Zimbabwean & 24 & $2(8.33 \%)$ & - \\
Mat Taib et al. (2017) & Malaysian & 44 & $2(4.55 \%)$ & - \\
Testut (1883) & French & 105 & $6(5.71 \%)$ & - \\
Venieratos \& Anagnostopoulou (1998) & Greek & 158 & - & $3(1.90 \%)$ \\
Present Study (2017) & Colombian & 106 & $4(3.77 \%)$ & $6(5.66 \%)$ \\
Average & - & - & $3.13 \%$ & $4.47 \%$
\end{tabular}


BALLESTEROS, D. R.; FORERO, P. L. \& BALLESTEROS, L. E. Variaciones anatómicas en relación al origen del nervio musculocutáneo: Ausencia y no perforación del músculo coracobraquial. estudio anatómico y significado clínico. Int. J. Morphol., 36(2):425-429, 2018.

RESUMEN: Las variaciones anatómicas más frecuentes del nervio musculocutáneo se pueden dividir en dos grupos principales: Ramas comunicantes con el nervio mediano y variaciones en relación al origen, que a su vez se pueden subdividir en la ausencia del nervio y la no perforación del músculo coracobraquial. Los síntomas clínicos inusuales y / o el examen físico inusual en pacientes con trastornos motores podrían explicarse por variaciones anatómicas del nervio musculocutáneo. Se evaluaron un total de 106 brazos, que corresponden a 53 cadáveres de machos frescos sometidos a necropsia. Se evaluó la presencia o ausencia del nervio musculocutáneo y si atravesó o no el músculo coracobraquial. Se midieron las longitudes de las ramas motoras y las distancias desde sus orígenes hasta el proceso coracoides. En 10 casos $(9,5 \%)$ se observó un patrón de origen inusual, de los cuales seis $(5,7 \%)$ corresponden a la no perforación del músculo coracobraquial y cuatro $(3,8 \%)$ corresponden a la ausencia del nervio. La longitud de la rama para el músculo braquial fue de $37,7 \pm 15,4 \mathrm{~mm}$ y para las cabezas cortas y largas del bíceps $27,6 \pm 11,7 \mathrm{~mm}$ y $33,2 \pm 10,1 \mathrm{~mm}$, respectivamente. El estudio mostró que nuestra población tiene una prevalencia similar de ausencia del nervio musculocutáneo y la no perforación del músculo coracobraquial comparado con informes previos en diferentes poblaciones. Además, no hubo una correlación estadística entre los lados y las variables evaluadas.

PALABRAS CLAVE: Variación anatómica; Nervio musculocutáneo; Nervio mediano; Plexo braquial; Lesiones en el brazo.

\section{REFERENCES}

Apaydin, N.; S en, T.; Bozkurt, M. \& Elhan, A. The anatomic branch pattern of the musculocutaneus nerve and its clinical implications. Turk. Klin. J. Med. Sci., 29(2):464-8, 2009.

Ballesteros, L. E.; Forero, P. L. \& Buitrago, E. R. Communication between the musculocutaneous and median nerves in the arm: an anatomical study and clinical implications. Rev. Bras. Ortop., 50(5):567-72, 2015.

Beheiry, E. E. Anatomical variations of the median nerve distribution and communication in the arm. Folia Morphol. (Warsz.), 63(3):313-8, 2004.

Buch-Hansen, K. Uber varietaten des nervus medianus und des nervus musculocutaneous und deren beziehungen. Anat. Anz., 102:187-203, 1955.

Bulla, A.; Farace, F.; Steinmann, G.; Montella, A. \& Uzel, A. P. About the absence of musculocutaneous nerve. Ital. J. Anat. Embiology., 117(2 Suppl.):29, 2012.

Chitra, R. Various types of intercommunications between musculocutaneous and median nerves: An analytical study. Ann. Indian Acad. Neurol., 10(2):100-4, 2007.

Choi, D.; Rodríguez-Niedenführ, M.; Vázquez, T.; Parkin, I. \& Sañudo, J. R. Patterns of connections between the musculocutaneous and median nerves in the axilla and arm. Clin. Anat., 15(1):11-7, 2002.

Gegenbaur, C. Uber das Verhaltniss des N. musculocutaneus zum N. medianus. Jena Ztschr. Med. Naturw., 3:258-63, 1867.
Guerri-Guttenberg, R. A. \& Ingolotti, M. Classifying musculocutaneous nerve variations. Clin. Anat., 22(6):671-83, 2009.

Hayashi, M.; Shionoya, K.; Hayashi, S.; Hatayama, N.; Kawata, S.; Qu, N.; Hirai, S.; Miyaso, H. \& Itoh, M. A novel classification of musculocutaneous nerve variations: The relationship between the communicating branch and transposed innervation of the brachial flexors to the median nerve. Ann. Anat., 209:45-50, 2017.

Kerr, A. T. The brachial plexus of nerves in man, the variations in its formation and branches. Am. J. Anat., 23(2):285-395, 1918.

Le Minor, J. M. A rare variation of the median and musculocutaneous nerves in man. Arch. Anat. Histol. Embryol., 73:33-42, 1990.

Loukas, M. \& Aqueelah, H. Musculocutaneous and median nerve connections within, proximal and distal to the coracobrachialis muscle. Folia Morphol. (Warsz.), 64(2):101-8, 2005.

Maeda, S.; Kawai, K.; Koizumi, M.; Ide, J.; Tokiyoshi, A.; Mizuta, H. \& Kodama, K. Morphological study of the communication between the musculocutaneous and median nerves. Anat. Sci. Int., 84(1-2):34-40, 2009.

Mat Taib, C. N.; Hassan, S. N.; Esa, N.; Mohd Moklas, M. A. \& San, A. A. Anatomical variations of median nerve formation, distribution and possible communication with other nerves in preserved human cadavers. Folia Morphol. (Warsz.), 76(1):38-43, 2017.

Osborne, A. W.; Birch, R. M.; Munshi, P. \& Bonney, G. The musculocutaneous nerve. J. Bone Joint Surg. Br., 82(8):1140-2, 2000.

Patel, S. J.; Patel, R. K.; Bhatt, C. \& Mehta, C. D. Variation of musculocutaneous nerve in arm with additional muscular slip in forearm. Int. J. Anat. Physiol., 2(3):20-2, 2013.

Prasada Rao, P. V. \& Chaudhary, S. C. Absence of musculocutaneous nerve: two case reports. Clin. Anat., 14(1):31-5, 2001.

Rea, P. Essential Clinically Applied Anatomy of the Peripheral Nervous System in the Head and Neck. London, Academic Press, 2016.

Standring, S. Gray's Anatomy. The Anatomical Basis of Clinical Practice. $41^{\text {st }}$ ed. New York, Elsevier, 2016.

Testut, L. Recherches anatomiques sur l'anastomose du nerf musculo-cutané avec le nerf médian. J. Anat. Physiol. Norm. Pathol. Homme Animaux, 19:103-8, 1883.

Tubbs, R. S. Nerves and Nerve Injuries: Vol. 2: Pain, Treatment, Injury, Disease and Future Directions. London, Academic Press, 2015.

Venieratos, D. \& Anagnostopoulou, S. Classification of communications between the musculocutaneous and median nerves. Clin. Anat., 11(5):327-31, 1998.

Yang, Z. X.; Pho, R. W.; Kour, A. K. \& Pereira, B. P. The musculocutaneous nerve and its branches to the biceps and brachialis muscles. J. Hand Surg. Am., 20(4):671-5, 1995.

Corresponding author:

Daniel Raúl Ballesteros Larrotta

Department of Basic Sciences

Medicine Faculty

Universidad Industrial de Santander

Cra. 32 \#29-31

Bucaramanga

COLOMBIA

E-mail: danielballesteros@live.com

Received: 20-11-2017

Accepted: $27-01-2018$ 